\title{
When Language Contact Says Nothing: A Contrastive Analysis of Queísta Structures in Two Varieties of Peninsular Spanish
}

\author{
José Luis Blas Arroyo \\ Professor of Spanish Linguistics, Faculty of Social Sciences and Humanities, \\ University Jaume I, Castelló de la Plana, Valencia, Spain \\ blas@fil.uji.es
}

\begin{abstract}
Based on the existence of some structural conflict between Spanish and Catalan in certain points of the syntax, this study tests the hypothesis about the influence of the latter on the distribution of queísmo uses ('Me alegro que vengas' ['I'm glad you come']) in the Spanish spoken in an eastern peninsular variety in contact with Catalan. Using the tools of comparative sociolinguistics, and the analysis of three corpora of contemporary Spanish, the study exhaustively examines the conditioning of this variable. The starting hypothesis is that the influence of the contact can be inferred from the comparison between different magnitudes derived from a multivariable statistical analysis. In addition to several linguistic and extra-linguistic predictors previously analysed in the literature, we also take into account other factor groups that may be particularly informative about that potential influence. Thus, from a structural point of view, we consider the contrast between: a) conjunctive queísmo in verbal structures, in which the structural conflict with Spanish is more evident ('me acuerdo (de) que vino con su mujer/em recorde Ø que va vindre amb la seua dona' ['I remember that he came with his wife']; and b) pronominal queísmo in relative sentences, in which the coincidence between both languages is greater ('el día (en) que nos conocimos / el día (en) què ens vam conéixer'). From an extralinguistic perspective, the incidence of two additional factors is also examined: a) the speech community (without contact (Madrid/Alcalá) vs. in contact (Castellón), and b) the main language of the speakers (Spanish/Catalan-Valencian). The results of several mixed-effect regression analyses performed do not support the hypothesis of contact. The distributional differences between the above-mentioned groups are minimal, and in no case significant. On the other hand, the variation is basically affected by the same
\end{abstract}


structural and non-structural predictors, regardless of the speech community or the ethnolinguistic group examined. Even the few divergences that are observed point in a direction contrary to that expected by the contact hypothesis. The study concludes with some potential explanations about these results and the contrast with other cases of syntactic convergence with Catalan.

\section{Keywords}

queísmo - languages in contact - language variation and change - corpus linguistics - Peninsular Spanish - Catalan

In Spanish syntax, the phenomenon of queismo refers to the absence of a preposition before the nexus que when it is required by an element in the sentence (verb, noun, adjective, etc.). Examples (1) and (2), taken from an oral corpus that is representative of the Spanish spoken in the speech communities of Castellón, illustrate this variation. In the first, the speaker joins the pronominal verb enterarse directly to the following subordinate clause with the conjunction que. In contrast, in (2), the same informant, with the same verb and in the same tense, now follows the standard variant (about this status, see Section 2), making use of the preposition.

(1) Papá Noel me ha traído unos pendientes, que me ha dicho mi madre que le han costa $(d)$ o... y encima, me he entera $(d)$ o yo también Ø que valen doscientos o trescientos euros (Mcscs, 227) ${ }^{1}$

[Father Christmas has brought me some earrings, which my mother told me cost... and, on top of that, I also found out that they cost two or three hundred euros]

1 The acronym mcscs name the Sociolinguistic Macrocorpus of Castellón and its regions, from which the example has been extracted (for more details concerning the composition of this corpus, see Section 4). On the other hand, the number (227) identifies one of the informants of this corpus. 
(2) ¿Te has enterado de que hay una cena en Villar Palasí, en el colegio donde estuviste en la EGB ${ }^{2}$ (MCSCS, 227)

[Have you heard that they are organising a dinner in Villar Palasí, the primary school you went to?]

In peninsular Spanish, this variation has occasionally been related to the influence of Catalan, a language that displays some differences in the construction of these structures (Seco, 1989; Badia, 1994; Gómez Torrego, 1999). Thus, in cases of queísmo dependent on verbs, nouns and adjectives, while in Catalan the governing element and the following subordinate clause are directly linked by que, in Spanish the two variants, with and without the preposition, have alternated throughout history (Lapesa, 1980; Cano, 1985; Gómez Molina and Gómez Devís, 1995; Serradilla, 1997; del Moral, 2004; Ruiz de Loizaga, 2005; Almeida, 2009; among others). Note, the difference between the following two examples.

(3) Cat. Estic segur que n'ha fet més de una (Mcscs, 392) 3

(4) Estoy seguro (de) que ha hecho más de una (Spanish translation)

[I'm sure he has done more than one]

Therefore, the hypothesis would be that, due to linguistic economy, in the Catalan linguistic domain, these differences could lead speakers to use the queista structures (common to both languages) more frequently than speakers of other dialectal varieties of Peninsular Spanish with no contact with the Catalan language. The same has also been posited in relation to other variation phenomena in which the influence of contact would bring about a significant increase in the frequency of uses of certain common forms, such as the deontic periphrasis haber de + infinitive - 'hemos de reaccionar' [we have to react] (Sinner, 2004; Blas Arroyo, 2004, 2011, 2015), or the pluralisation of the presentational uses of haber - 'habían cinco personas' [There were five people]) (Blas Arroyo, 2018). On the other hand, within the varieties in contact with Catalan, it could also be expected that there will be a significantly greater use of queísmo among bilinguals who have a prevalent use of this language than among those whose dominant or exclusive language is Spanish.

2 EGB is the acronym for the educational law known as Educación General Básica (Basic General Education), which was in force in Spain during the 7os and 8os of the last century.

3 The transcription of the examples in Catalan from the Castellón corpus is literal and does not conform to normative criteria. On many occasions, speakers make a use of the language that is far from the standard. 
To test these hypotheses, in the present study we will compare the distribution of the queista structures in two dialectal enclaves that are sufficiently differentiated from each other, namely, the city of Castellón and its metropolitan area, on the one hand, and two Spanish-speaking communities representative of central Spanish, Alcalá de Henarés and the city of Madrid, on the other. However, to be able to detect the influence of contact as a potential explanatory factor, things are not as simple as merely comparing the frequencies of use in one region and another. In practice, and as highlighted by Poplack et al. (2012: 205), to confirm the influence of this contact “... it is not sufficient to simply verify the existence of vernacular uses that are more or less extended throughout the speech community. On the contrary, it is necessary to provide empirical evidence of certain requirements". Although these postulates are fundamentally designed to account for the outcomes of linguistic change caused by contact, some of the requirements may well extend to the explanation of other outcomes of variation, such as the one we analyse in these pages. In particular, we are interested in two of the requisites mentioned by these authors.

a) That the vernacular variants behave in a manner similar to that found in the other language.

b) That the variation patterns of these variants differ significantly from those observed in other varieties of the same language.

In the absence of a systematic contrastive analysis of Spanish and Catalan on this grammar point, in this article we will explore the second condition in depth, through an exhaustive comparison of the patterns of variation seen in different speech communities and ethnolinguistic groups. On the other hand, in addition to the structural conflict sites previously noted in conjunctive utterances such as (3) and (4), the syntax of Spanish and Catalan also shows some equivalence in the so-called pronominal queismo, which we find in some relative clauses. Thus, in (5) and (6), the two languages coincide in the normative use of the preposition en before the relative pronoun (albeit unstressed in Spanish and stressed in Catalan).

(5) Ara, aplega el moment en què una persona... un matrimoni vol tindre familia (MCsCs, 359)

(6) Ahora, llega un momento en que una persona... un matrimonio quiere tener familia (Spanish translation)

[Now, there comes a time when a person... a married couple wants to have a family] 
In short, contact with Catalan could lead to different outcomes in distinct linguistic and extralinguistic contexts, so we need more sophisticated tools than a simple comparison of frequencies if we want to fully account for this potential influence. In order to unravel this complexity, in this study we use the traditional instruments of sociolinguistics, and in particular the analysis of mixed effects logistic regression, in which the predictors under review are evaluated in conjunction with others that have already been considered in the previous literature. Moreover, in the present study, this quantitative methodology is completed with the tools of comparative sociolinguistics, a method that involves analysing the connection between the patterns of variation presented by different subsamples in the same corpus (Tagliamonte, 2012:162).

The paper is structured as follows. In Section 2 we briefly review the current status of the linguistic variable as regards the main historical, typological, sociolinguistic and dialectal issues concerning queista constructions in current Spanish - and their comparison with Catalan - in order to better define the object of study. In Section 3, this review is completed by giving an account of the envelope of variation, which in the present study is limited to the contexts of conjunctive queismo dependent on verbal constructions, on the one hand, and to pronominal queismo in prepositional relative clauses, on the other. Section 4 summarises the main details of the oral corpus used in the study, and the most important methodological issues are outlined in Section 5 , in which we will examine in detail both the coding process and the statistical tools used. The main results of the research are presented and analysed in Section 6, and their most important implications, including the contrast with other phenomena of potential linguistic convergence with Catalan, are discussed in the final section (Section 7).

From a prescriptive point of view, queísmo "is [currently] perceived as an anomaly of less significance than dequeísmo" (RAE and ASALE, 2009: 3252), a phenomenon with which it has often been linked (Rabanales, 1974; García, 1986; Schwenter, 1999; Guirado, 2009). Gómez Torrego (1999: 2133-2134) points out, however, that there are some important differences between them. For example, dequeísmo only affects the preposition de ('Pienso de que aquí en España se juega un futtbol diferente' [I think that here in Spain football is played differently]), which is not the case with queismo, where the list of possible prepositions is longer (de, a, por, en, con). On the other hand, queismo is also possible in relative clauses ('Es el día (en) que naci' [it is the day I was born]), which is 
a far more sporadic possibility in samples of dequeísmo. Finally, queísmo is far more frequent and much less censored than dequeismo, to the point where, in some constructions, both alternative variants are considered correct (RAE and ASALE, 2OO9: 3252).

Whereas the dating of dequeísmo is not altogether clear in the history of Spanish (DeMello, 1995: 141; Gómez Molina and Gómez Devís, 1995: 196), there is a relative consensus about the age of the queista constructions, of which we find testimonies throughout the medieval and the classical Spanish periods (del Moral, 2004: 121-169; Herrero Ruiz de Loizaga, 2005: 87-92; Kany, 1969: 408-411). In fact, in an account of the constructions considered here in an epistolary corpus from the Spanish Golden Age, we find a clear prevalence of queista structures over non queista ones, in a process that nevertheless became more moderate and was, in some cases, inverted in subsequent centuries (Blas Arroyo y Velando, in preparation).

Typologically, queísmo is usually grouped into two large blocks (Gómez Torrego, 1999: 2135-2145). The term conjunctive queismo is used to refer to constructions in which the preposition disappears in the introduction of complementary subordinates dependent on: a) pronominal verbs (me enteré (de) que [I found out that]); b) non-pronominal verbs (trato (de) que [I try to...]); c) adjective complements, either in attributive structures (estoy seguro (de) que [I'm sure that]), or in passive constructions with participles (he sido informado (de) que [I've been informed that]); d) noun complements, often within semi-locutionary structures with supporting verbs (me he dado cuenta (de) que [I've realised that]); e) conjunctive (a pesar (de) que [although ...]) and adverbial phrases (encima (de) que [on top of that...]), and f) other isolated cases (es hora (de) que [it's time...]).

On the other hand, pronominal queismo implies the suppression of a preposition before the relative pronoun que when the former is required by the antecedent. It appears in: a) equational structures (fue por María (por quien) que supe que te ibas [it was through Mary that I knew you were leaving]); b) with the relative pronoun acting as dative (hay personas (a las) que les cuesta [there are people who find it hard to...]); c) adverbial clauses (es la casa (en la) que vivo [It's the house I live in]); d) noun complement (the so-called quesuísmo: 'es la mujer (cuyo) que su marido ganó el premio' [It's the woman whose husband won the award]); and e) constructions with the same preposition in the antecedent (en la fábrica (en la) que trabajo hay aire acondicionado [in the factory where I work there is air conditioning]). For the present study, we have selected some of the most frequent cases from both groups, the details of which we reserve, however, for Section 3. 
Various reasons have been put forward to account for the causes of queismo, ranging from syntactic phonetics (the elision of the preposition de in intervocalic contexts such as estoy seguro de, where the consonant/d/ is particularly weak), to hypercorrection, especially among speakers who are more aware of the stigmatisation of dequeismo, which would lead to the elision of de in all cases, including those that are correct (García Yebra, 1990). However, such reasons do not explain all types of queismo, such as the pronominal cases, in which the preposition most commonly involved is not usually de but instead $e n$. On the other hand, it would be necessary to prove that the elision affects intervocalic contexts significantly more than non-intervocalic ones, a task still pending. Mention has also been made of linguistic economy, a universal principle which would go against the redundancy of the complementiser in practice present in few languages, such as Spanish and Portuguese, but not in many others, including those of the same Romance stock (French, Italian, Catalan, etc.). Another factor cited is the analogy with similar structures, but whose syntactic schemas differ (Rabanales, 1974: 415; Seco, 1989: 199). Thus, Gómez Torrego (1999: 2140) points out that constructions like Concluyeron que presentarian un proyecto [They concluded that they would present a project] could account for the spread of queismo in other equivalents such as Llegaron a la conclusión que [They came to the conclusion that...]. And the same occurs with: a) verbs like the pronominal acordarse, whose extremely high rates of queísmo (see Section 6.1) could be explained, at least in part, by crossing with recordar (Recuerdo que...[I remember that...]); b) attributive structures like está seguro (de) que [she/he's sure that], based on what happens with the same adjective and the verb ser (Es seguro que...[It's certain that...], or even c) in conjunctive phrases like en vista (de) que [in view of the fact that...], due to contagion with other similar cases such as una vez que [once...] or a no ser que [unless...].

From the socio-stylistic point of view, we have already noted how the Nueva gramática (RAE and ASALE, 2009) considers queísmo as an "anomaly" of less importance than dequeísmo, in relation to which it adds "...it is frequently observed in formal registers, and some of its variants are considerably widespread" (p. 3252). In fact, in a questionnaire about attitudes towards both dequeísmo and queísmo in the city of Valencia, Gómez Devís (1996: 315) obtained barely $15 \%$ of stigmatisations for the latter, compared with much higher rates for the former $(70 \%)$. Even so, academic institutions today still consider more recommendable and correct the constructions with a preposition in phrases with supporting verbs (darse cuenta (de) que [to realise that...], dar la casualidad (de) que [happen to be...]), conjunctive phrases (en caso (de) que [in the event that...]), pronominal (olvidarse (de) que [to forget that...]) and 
non-pronominal verbs (insistir (en) que [to insist that...]), and attributive structures, such as estar seguro [to be sure that...], although, in many of these cases, the queista variant is prevailing and in some instances is almost categorical (the case of acordarse, for example, which we will come back to later in Section 6.1).

Dialectal variation is also noticeable, so that the frequencies of queismo may differ considerably from one regional variety to another. The variation has been studied from a dialectological point of view, and, in recent times, also from a sociolinguistic one, in several Spanish-speaking communities from America (cf. Rabanales, 1974; Arjona, 1978; Boretti de Macchia, 1989; Bentivoglio y Galué, 1998-1999; Schwenter, 1999; del Moral, 2004; San Martín, 2016, among others) and, to a lesser extent, Spain (Carbonero, 1992; Gómez Molina and Gómez Devís, 1995; Gómez Molina, 2013; Almeida, 2009). The frequencies of use obtained in these studies differ considerably both in terms of extralinguistic factors - generally greater queismo at popular levels than in cultured speech - and typological ones (higher rates in pronominal queismo than in conjunctive queismo, although with important differences also within the latter). However, the results of these studies are not always comparable, given the significant methodological differences between them, as well as the not always precise delimitation of the envelope of variation.

Of particular interest for our object of study is the potential influence of other languages. In this respect, Gómez Torrego (1999: 2140) mentions the spread of queismo in the written language owing to translations into Spanish of other languages in which both the preposition and que does not take place together. Moreover, in the spoken (and written) language, the influence of Catalan has also been mentioned. On this matter, Gómez Torrego states as follows:

Many Catalan speakers, even educated ones, are queistas when they speak Spanish, undoubtedly due to linguistic differences with respect to Catalan [our italics]. It is very common among this type of speaker to hear things like [*] el hecho que por el hecho de que (in Catalan: el fet que) [the fact that...], [*] tengo la esperanza que instead of tengo la esperanza de que (in Catalan: tinc la esperança que...) [I'm hoping that...], [*] estoy seguro que (in Catalan: estic segur que) [I'm sure that...], etc. [On the other hand] It has already been said [...] that dequeísmo in Catalan-speaking areas is largely a phenomenon produced by hypercorrection [our translation] (p. 2140).

Indeed, unlike Spanish, where the dropping of the preposition is usually considered as a non-normative expression, the opposite occurs in Catalan subordinate clauses. Thus, the use of the unstressed prepositions ( $a$, de, en, amb) is not allowed before the conjunction que, even when the governing element 
(noun, adjective or verb) is normally constructed with them in other constructions (Fabra, 1956: 205-206; Marvà, 1985: 288; Badia, 1994: § 240; 256, 6; Wheeler et al., 1999: 552; Lacreu, 2000: 349). In this regard, note the difference between examples (7-8) and examples (9-10).

(7) Catal. Ha ixit tot bé, no tinc queixa de ningú (MCSCs, 310)

(8) Ha salido todo bien, no tengo queja de ninguno (Spanish translation) [Everything has gone well, I have no complaints about anyone]

(9) Catal. La meua dona se queixe que la casa...la cuina està ja vella (MCsCs, 352)

(10) Mi mujer se queja (de) que la casa...la cocina está ya vieja (Spanish translation)

[My wife complains that the house...the kitchen is already an old one]

Even when the grammarians admit that the oral language contains frequent examples with the preposition ("Es queixaven de que els tractaves malament"), "this construction is absolutely incorrect and unacceptable" (Badia, 1994: § $250,6)$.

An altogether different case is that of relative time clauses, where we find greater structural similarities with Spanish. Therefore, in Catalan (as in Spanish) relative clauses connected with a noun that encloses a notion of time (dia, hora, any, moment, etc.) frequently use the relative pronoun que without any kind of preposition.

(11) Catal. El dia que va faltar, el dia anterior, havia millorat un poquet (MCSC, 395)

(12) Span. El día que murió, el día anterior, había mejorado un poquito

[The day he died he had improved a little bit]

However, as in Spanish, the Catalan pronoun can also be combined with a preposition in these relative clauses. The main difference is that, the unstressed pronoun becomes stressed in Catalan ("eren uns anys en què tots vam patir fam" [Those were a few years when we all went hungry]) (Fabra, 1956: 198-200; Marvà, 1985: 220; Badia, 1994: § 140; Wheeler et al., 1999: 536). ${ }^{4}$

As we have pointed out, in this study we test the hypothesis about the possible influence of Catalan on the diffusion of the queista structures in the Spanish of the Catalan-speaking regions and, more specifically, in the speech

4 For authors such as Weeler et al. (1999: 536), this rule applies when the antecedent is introduced by an indefinite article ("eren uns anys en què tots vam patir fam"). However, other grammarians do not consider this exception and also give examples with another kind of nominal determination. 
communities of Castellón, where the two languages maintain a secular contact. With this aim in mind, we will compare the patterns of variation observed with other Peninsular varieties, as well as among different ethnolinguistic groups. Before addressing these extralinguistic predictors, however, in the following section we summarise the envelope of the variation dealt with by the analysis.

\section{The Envelope of Variation}

As stated above, the context to which this study is restricted encompasses several of the syntactic constructions referred to in Section 2. To facilitate the variationist analysis, we have limited the study to the most productive of them, that is, those that appear in the corpus with a sufficiently representative frequency.

On the one hand, there are cases of conjunctive queísmo in verbal structures, which in turn are divided into three groups.

1. Pronominal verbs: acordarse, alegrarse, asegurarse, avergonzarse, empeñarse, enterarse, preocuparse, olvidarse, quejarse.

2. Non-pronominal verbs: advertir, ${ }^{5}$ amenazar, avisar, convencer, cuidar, depender, dudar, esperar, hablar, informar, insistir, tratar.

3. Verb phrases (the most common supporting verbs are shown in brackets): (tener, caber) duda, (tener) cuidado, (dar(se)) cuenta, (llegar al) acuerdo, (tener) gana(s), (tener) suerte, (tener la) impresión, (tener la) sensación, (dar(se)) casualidad, (dar(se)) circunstancia, (dar) coincidencia, (llegar a la) conclusión.

The same criterion has been used with the second block of queista constructions, that is, the ones that affect the pronoun que in relative clauses. The following is a list of nouns that act as antecedents in these cases.

4. Relative clauses (antecedents): año, día, época, hora, lugar, momento, mundo, ocasión, sitio, situación, tiempo, vez, zona.

5 In its sense of 'make something known to someone' ('le advierto (de) que no será tan fácil la próxima vez'). In contrast, in its interpretation of 'realising [something] or noticing [something], the predicate is transitive and is constructed without a preposition (Diccionario Panhispánico de dudas, 2005; http://lema.rae.es/dpd/?key=advertir, last accessed: 02/07/2020). 
Most of these nouns appear very commonly in speech and enclose temporal and, in some cases, locative meanings, while in their relative constructions the pronoun que acts as an adverbial.

The materials for the study were drawn from three oral corpora compiled in recent years and which are representative of three Spanish speech communities. Two of them, those focused on the speech of Alcalá de Henares (Moreno Fernández, Cestero, Molina, and Paredes, 2002-2007) and Madrid (Salamanca district) (Cestero, Molina and Paredes, 2012), are part of the PRESEEA project (Proyecto para el estudio sociolingüístico del español de España y de América), and have been published in recent years. ${ }^{6}$

The other corpus is the Macrocorpus sociolingüistico de Castellón y sus comarcas [Sociolinguistic macrocorpus of Castellón and its regions] (MSCSCS), which was developed at the turn of the last century (1998-2006) by the Sociolinguistics Laboratory of the Universitat Jaume I. This corpus is mainly based on sociolinguistic interviews carried out in Spanish, but it also includes a sample of interviews in Catalan with some of the bilingual members of the corpus for comparative purposes.

Located in the east of Spain, Castellón is the northernmost province of the Autonomous Community of Valencia, which also includes Valencia and Alicante. Although it is the least populated province of the Community, it has the highest concentration of Valencian-speaking population, so it provides a good testing ground for analyzing the linguistic outcomes of language contact. As shown by the survey Coneixement $i$ ús social del valencià [Knowledge and social use of the Valencian Language,${ }^{7}$ published by the Conselleria de Educació in 2015, Castellón leads, in fact, the use of Valencian in the Community, with $65.8 \%$ of the population that speaks the language, although the degree of use varies depending on several factors, such as the social domain of use (more in domestic than in formal contexts) or the habitat (more in the villages than in the capital of the province, Castelló de la Plana). Moreover, the duration of this contact between Catalan and Spanish in the region is multi-secular, since

6 My most sincere gratitude goes to the coordinators of both projects for their kindness in allowing me access to these materials.

7 Valencian is the term commonly used to name the Catalan language in the Valencian Community. Nevertheless, for expositive and stylistic purposes, in the article we will use both terms interchangeably, along with the current official name (Valencian-Catalan) of the language, all of which designate the same linguistic reality. 
Castellón

Alcalá de Henares

Madrid (Salamanca district)

it dates back to the sixteenth century, although only from the twentieth century onwards has intensified among the most popular sectors, which has led to a significant shift of the native language by the Spanish (Ninyoles, 2000).

These three corpora are comparable not only because they were constructed at around the same time, but also due to the methodology used to create them, namely, semi-structured interviews lasting an average of approximately $45^{-} 50$ minutes. During their development, the anthropological method of life stories was combined with other thematic modules with the aim of obtaining different kinds of texts (expository, narrative, argumentative, etc.). In addition, all the corpora are initially stratified by similar quotas of gender, age and level of education.

This process has enabled us to obtain samples of speech produced by 231 speakers, distributed in an irregular manner in the three speech communities mentioned above (Table 1). However, to facilitate the quantitative analysis, and given the similar magnitudes obtained in the two areas of Madrid (see Section 6.1), for the regression analysis we join these two together and compare their results with those of Castellón.

\subsection{Coding}

A concordance program (Wordsmith 6.o) was used to find all the occurrences of the forms outlined in Section 3 in the corpus. Each example was coded according to several linguistic, stylistic and social predictors to which the previous literature has drawn some attention, because of their relevant contribution to the variation dealt with here (Rabanales, 1974; Bentivoglio and Galué, 1998-1999; Boretti de Macchia, 1989; Carbonero, 1992; Gómez Molina and Gómez Devís, 1995; Schwenter, 1999; Guirado, 20o9; Almeida, 2009; San Martín, 2016; among others).

As regards linguistic predictors, we considered the following. 
1. Typology: as stated above, the cases of queísmo are grouped into four blocks, three related to verbal conjunctive queísmo (pronominal verbs, non-pronominal verbs and nominal clauses with supporting verbs) and one pronominal, that of relative clauses. For the regression analysis, the first three are grouped together and are set against pronominal queismo. However, in the specific examination of conjunctive queísmo (see Section 6.3), the three categories will be analysed separately.

The initial hypothesis is that the queista variants will be more frequent in relative clauses than in verbal constructions.

2. Degree of adjacency between the governing element and the complementiser. In this respect, we distinguish between two levels, which are exemplified below.

Adjacent:

(13) ...creo que era sí doscientas me acue... me acuerdo que valía dos mil pesetas la tira ¿no? y claro echas cuentas y dices me estoy dejando cincuenta mil pelas todos los meses (Madrid, 26)

[... I think it was, yes, two hundred I remem... I remember that it cost two thousand pesetas a strip, right? and of course you do some adding up and find you're losing fifty thousand pesetas every month]

Non-adjacent:

(14) Yme lo llevaba a mi casa porque a mi hermano le gustaba y se lo comía él [...]Y me a... me acuerdo eso/de que en aquella época lo que estaba lleno de macetas, el colegio, que eran los botes metálicos aquellos de los americanos... (MCSCs, 18 )

[And I took it home because my brother liked it and he ate it [...] And I rem... I remember that/ that at that time what was full of flowerpots, the school, which were metal pots, those American ones...]

In (13) the pronominal verb acordarse is directly linked to que, while in (14) one word (eso) and a brief pause are placed between the two elements. Cognitively, it is to be expected that the distance between the governing element and the complementiser will favour elisions to a greater extent than their

8 The corpus (in this case, the Corpus preseef of Madrid) and the identification of the informant in each case (26) appear in parentheses. The same criteria applies to the remaining examples. 
adjacency, since the speaker may lose control over the syntactic structure governed by the verb.

3. Frequency: in this case, we resorted to the frequency of the queista structures in the corpus. According to the idea about the importance of this factor in many instances of linguistic variation and change (Bybee, 2006), the hypotheses is that the greater the frequency of these constructions is, the higher the rates of queísmo will be.

4. Priming: understood as referring to the hypothetical incidence in the linguistic variable of the material used in the immediately previous context (Pereira-Scherre and Naro, 1992; Rosemeyer and Schwenter, 2017), which, for its operationalisation in this study, we limit to the ten previous words. ${ }^{9}$ Our interpretation is, therefore, far more restrictive than that of the authors who consider the positive effect of this priming in far more extensive contexts (Pickering and Ferreira, 2008: 447). In our view, however, the assimilatory or dissimilatory influence of certain elements on the presence or absence of the preposition is only guaranteed when they are close together, and becomes considerably weaker as the distance between them increases.

There are three levels that derive from this predictor.

1. Presence of que in the previously mentioned context. For stylistic reasons, we could expect that the wish to avoid repeating two formally identical elements in such a short space leads to fewer queista uses in this context.

(15) ... y que hay que cambiar pero en la época en que yo era pequeña pues no todo el mundo... casi nadie tenía coche para ser sinceros (Madrid, 11) [... and you have to change but at the time in which I was small well not everybody... hardly anybody had car to be honest]

2. Presence of the same preposition (nearly always de in conjunctive queísmo and en in the pronominal one), as in (16), with similar expectations to those seen above.

(16) No sé, no me acuerdo de su cara, me acuerdo de que entraron dos nuevas cuando la Nuria y yo ya estábamos en pleno rebote (MCSCS, 302)

9 This is the approximate number of words that we find before the governing element on the concordance list that the Wordsmith program produces by default (6o characters). 
[I don't know, I don't remember her face, I remember that two new ones came in when Nuria and I were quarrelling]

3. Others: absence of both elements in the previous setting. This is the most frequent context in the corpus, and in it we expect different results to the previous ones.

(17) ... era una tontería una tontería y estábamos allí viene una ola, otra ola/ pero cuando te ves en ese momento que no puedes hacer nada, que el mar tira de ti... (MCSCs, 126)

[it was silly, silly, and there we were and in comes a wave, another wave/ but when you see yourself in that situation you can't do anything, that the sea is pulling you...]

5. Polarity: crucial in numerous outcomes of variation and change (Givón, 1979; Poplack and Dion, 2009), in this study we seek to assess the opposition between affirmative sentences, which are the majority, and others in which a negation intervenes, either in the main or in the subordinate clause.

6. Person: this predictor is considered only in cases of verbal queismo (see Section 6.3). With it, we wish to test the hypotheses about the potential iconic role of the preposition (García, 1986), reinterpreted by some authors as a resource of evidentiality (Schwenter, 1999; Guirado, 20o9). In this sense, we distinguish between the forms of the 1st person, which coincides with the subject of the enunciation, and the other persons, in which the speaker, logically, has less control over the content of the subordinate clause. Following Schwenter (1999), the initial hypothesis is that the absence of the preposition will be greater in the instances of the 1st person, followed by the 2 nd person. In contrast, the 3 rd person will be the context that is most likely to contain the preposition.

(18) ... yya te digo que podemos... tenemos montado nuestros belenes nuestros tinglados pero que ante esa situación de que (yo) no les he conseguido convencer de que no hace falta montar tanta mesa y yo lo paso muy mal (Madrid, 46)

[... and I'm telling you that we can ... we have set up our nativity scenes, our things but faced with this situation in which I have not managed to convince them that there is no need to put on so many tables and it gives me a hard time]

(19) ..., me parece muy bien, yo sí que acepto una transfusión de sangre, pero a mí no me van a convencer que me haga de los suyos (MCsCs, 277) 
[..., it sounds great to me, I do accept a blood transfusion, but they're not going to convince me to allow them to do what they want with me]

7. Structure, understood as referring to each of the constructions noted in Section 2.

The following extralinguistic factors have also been taken into account.

1. Gender: Males and females.

2. Level of education: Primary, secondary and higher.

3. Community: Castellón and Madrid (Alcalá de Henares and the Salamanca district).

4. Dominant language: Spanish and Valencian-Catalan. ${ }^{10}$

5. Age: four groups: > 25 years; $26-40$ years; 41-6o years; over 61 years.

6. Informant: each of the members of the sample.

For a mixed effects regression analysis, both frequency and age are considered as continuous predictors, while the structure and the informants' identity are interpreted as random variables. The others are fixed factor groups, given that their content is entirely compartmentalised at the levels referred to.

In the analysis, the presence of que without a preposition acts as the application value. All the other cases are subsumed in a second variant, where that complementiser - conjunction or relative pronoun - is preceded by a preposition. Among the possible particles, there are two that are far more frequent than the others: de in conjunctive queísmo and en in pronominal queísmo. However, these prepositions occasionally give way to others, depending on the particularities of each governing element. Of these, the most frequent are $a$ and con, exemplified below in (20) and (21), although the two represent but a tiny percentage of the total.

10 As previously mentioned (see Section 4), almost $60 \%$ of the population of Castellon has an active competence in Valencian, while the rest is able to understand it perfectly, but normally expresses in Spanish, so practices such as dualinguism - the conversation of each speaker in his or her own language - are not uncommon. However, within the group of Valencian speakers there are some noticiable differences. Thus, a majority has Valencian as their mother tongue from the very beginning, and makes a majority use of it in their daily lives, while others have learned it later (generally in school), with Spanish being their clearly dominant language. Therefore, for the purposes of the analysis, the members of the latter group are joined to the exclusive speakers of Spanish - with only a passive competence on Valencian and face those who have Valencian as their main language (for other possible interpretations and operationalizations on bilingualism and dominance, see Silva-Corvalán and Treffers-Daller, 2015). 
...amigo no le pido nunca nada (lapso = 3) no le pido nunca nada/ si él es amigo mío si yo soy amigo suyo si veo que está necesitado voy a decírselo/ no espero a que me lo digan (Alcalá, 27)

[...friend I never ask him for anything (lapse = 3) I never ask him for anything/ if he is a friend of mine if I am a friend of his if I see that he is in need I will tell him/ I don't wait for him to tell me]

(21) Yademás amenazaba con que si quitábamos el dedo nos pasaría algo esa noche (MCSCs, 85)

[And he also threatened that if we lifted our finger, something would happen to us that night]

\subsection{Statistical Analysis}

For the quantitative study we used the program Rbrul (Johnson, 20o9), which allows us to perform a mixed-effects regression analysis, in which it is possible to consider not only categorical predictors, but also continuous and random ones. The presence of the latter is especially relevant, as it allows statistical information on categorical variables to be filtered through the sieve of intradialectal (informants) or syntactic (structures) variation. This endows the results with greater reliability, which might otherwise be compromised by excessive recursiveness in certain enclaves of the data (for some cases of this type, see Section 6.1 below). Moreover, Rbrul allows the automatic analysis of potential interactions between two fixed predictors, as well as access to three of the fundamental measures of any variationist study: a) the list of predictors selected and not selected as significant; b) the explanatory force of each factor, which are measured in factor weight values situated between the limits of zero (null selection) and one (categorical selection); and c) the direction of effect among these factors within each predictor.

The latter is especially relevant in the comparative application of this quantitative methodology, which involves performing independent regression analyses on different comparable corpora or subsamples of the same one, such as those we will carry out here. The idea underlying this approach is that the

TABLE 2 General distribution of frequencies by type of queísmo

\begin{tabular}{lrcr}
\hline TYPE & N & $\%$ & $\Sigma$ \\
\hline Pronominal Verbs & 363 & 83 & 438 \\
Non-Pronominal Verbs & 76 & 39 & 193 \\
Verbal phrases & 170 & 40 & 427 \\
Relative clauses & 1250 & 82 & 1520 \\
TOTAL & 1859 & 72 & 2578
\end{tabular}


TABLE 3 Comparison between the distributions of acordarse it vez and the remaining governing words in each group

\begin{tabular}{lccc}
\hline PRONOMINAL VERBS & N & \% & $\Sigma$ \\
\hline Acordarse & 317 & 94 & 338 \\
Remaining verbs & 46 & 46 & 100 \\
TOTAL & 363 & & 438 \\
RELATIVES & & & \\
Vez & 397 & 98 & 404 \\
Remaining nouns & 852 & 76 & 1116 \\
TOTAL & 1249 & & 1520 \\
\hline
\end{tabular}

structure of variation, and the hypothetical similarities or differences between different varieties or social groups, can be glimpsed from a comparison between their corresponding quantitative magnitudes (Poplack and Tagliamonte, 2001; Torres Cacoullos, 2011).

\section{$6 \quad$ Results and Analysis}

\subsection{General Results}

Table 2 shows the distribution of the queista tokens according to the four grammatical categories initially considered. Out of a total of 2578 examples, the table highlights the overwhelming majority of this variant among relative clauses, in pronominal queismo $(82 \%)$, unlike the conjunctive queísmo with non-pronominal verbs $(39 \%)$ and verb phrases $(40 \%)$, both of which are present in considerable proportions, but at a great distance from the former.

A particular analysis, however, requires the group of pronominal verbs, whose high figures $(83 \%)$, similar to those of pronominal queismo, nevertheless conceal an important bias - that introduced by the form acordarse, which alone accounts for three quarters of all the samples in this block. In fact, and as can be seen in the Table 3 , the behaviour of this verb differs radically from that observed among the other members of the pronominal verbs, so that no less than $94 \%$ of all occurrences of acordarse are resolved by means of the queista

11 Several references to the over-abundance of queista forms with this verb can also be found in the literature (Rabanales, 1974: 427; Arjona, 1978: 76; Carbonero, 1992: 47; Gómez Torrego, 1999: 2136). 
TABLE 4 Redistribution of frequencies by type of queismo in the final sample

\begin{tabular}{lccc}
\hline TYPE & N & \% & $\Sigma$ \\
\hline Pronominal Verbs & 46 & 46 & 100 \\
Non-Pronominal Verbs & 76 & 39 & 193 \\
Verbal phrases & 170 & 40 & 427 \\
Relative clauses & 852 & 76 & 1116 \\
TOTAL & 1144 & 62 & 1836 \\
\hline
\end{tabular}

variant. However, these proportions drop to less than half in the remaining verbs $(46 \%) .{ }^{11}$ Moreover, the same happens with one of the nouns that act as antecedent in relative clauses $(\mathrm{vez})$, whose figures are also practically categorical $(98 \%)$, unlike the other nouns, where the selection of the queista variant is high, but not so overwhelming $(76 \%)$.

Given the disturbance that these practically categorical choices could introduce in the results, both have been eliminated from the final sample, which is finally made up of the figures in Table 4. There we can see how the distributional patterns of the three verbal subsets is now similar (around $40 \%$ of queista forms) and significantly different from the relative ones, so we will group them in a single block for the subsequent regression analyses.

The differences between the two types of queismo, conjunctive and pronominal, are supported by the regression analysis. Moreover, it appears as the strongest predictor of all those considered. As the results in Table 5 show, in the whole sample, the relative clauses favour the queista variants in the two parallel analyses carried out, i.e., when both the linguistic structure (.63) and the identity of the informants (.67) are considered as random factors. ${ }^{12}$

Although to a lesser extent, the variation is also sensitive to the degree of adjacency and to the frequency of the constructions in speech. In the first case, the adjacency between the governing element and que has a moderately unfavourable effect on the queista variant (.44), unlike the contexts in which other elements come between the two, where the favourable incidence is also slight (.55). These results seem to support the hypothesis we started out from (see Section 5.1), that is, that the distance between the two elements gives rise to a blurring of the syntactic sub-categorization and, therefore, a reduced presence of the preposition. Similarly, the correlation between the frequency of the

12 For the sake of economy and space, from now on we will only report on the results of the first analysis, although a comparison between the two shows very similar results, confirming their congruence and reliability. 
TABLE 5 Contribution of various linguistic and extralinguistic predictors to the selection of queismo variants in the corpus

\begin{tabular}{|c|c|c|c|c|c|}
\hline & $\mathrm{N}$ & $\%$ & $\Sigma$ & FW. (Infor.) & $\begin{array}{c}\text { FW. } \\
\text { (Struct.) }\end{array}$ \\
\hline \multicolumn{6}{|l|}{ Type } \\
\hline Verbs & 292 & 41 & 720 & .37 & .33 \\
\hline Relative clasuses & $85^{2}$ & 76 & 1116 & .63 & .67 \\
\hline \multicolumn{6}{|l|}{ Adjacency } \\
\hline Adjacent & 999 & 61 & 1617 & .44 & .43 \\
\hline No & 145 & 66 & 219 & .55 & .57 \\
\hline Frequency (continuous) & & & & +10.002 & \\
\hline \multicolumn{6}{|l|}{ Priming } \\
\hline No & 793 & 62 & 1276 & - & - \\
\hline Que & 244 & 63 & 390 & - & - \\
\hline Preposition & 107 & 62 & 170 & - & - \\
\hline \multicolumn{6}{|l|}{ Polarity } \\
\hline Afirmative & 1001 & 63 & 1578 & - & - \\
\hline Negative & 143 & 55 & $25^{8}$ & - & - \\
\hline \multicolumn{6}{|l|}{ Gender } \\
\hline Males & 464 & 61 & 765 & - & - \\
\hline Women & 680 & 63 & 1071 & - & - \\
\hline \multicolumn{6}{|l|}{ Level of education } \\
\hline Elementary & 347 & 75 & 465 & .64 & .63 \\
\hline Secondary & 467 & 67 & 700 & $.5^{2}$ & $.5^{2}$ \\
\hline Higher & 330 & 49 & 671 & $\cdot 35$ & .35 \\
\hline \multicolumn{6}{|l|}{ Communities (grouped) } \\
\hline Castellón & 688 & 61 & 1127 & - & - \\
\hline Madrid & $45^{6}$ & 64 & 709 & - & - \\
\hline \multicolumn{6}{|l|}{ Dominant language } \\
\hline Spanish & 799 & 63 & 1278 & - & - \\
\hline Valencian-Catalan & 345 & 62 & $55^{8}$ & - & - \\
\hline \multicolumn{6}{|l|}{$\begin{array}{l}\text { Dominant language } \\
\text { (only Castellón) }\end{array}$} \\
\hline Spanish & 343 & 60 & 569 & - & - \\
\hline Valencian-Catalan & 345 & 62 & $55^{8}$ & - & - \\
\hline Age (continuous) & - & & - & - & \\
\hline
\end{tabular}

INFORMANT: $N=1836$; INTERCEPT: -0.034; LOG.LIKELIHOOD: -991,044; AIC: 1996,15; DXY: .70; INPUT: .62

STRUCTURE: $N=1836$; INTERCEPT: 0.393; LOG.LIKELIHOOD: -947,566; AIC: 1907.178,15; DXY: .65; INPUT: .62 
queista structures and the greater selection of these variants is also confirmed by the results.

In contrast, the data from the analysis do not support the hypothetical influence of priming, so that the presence or absence of a preposition or que in the previous context does not act in any particular direction. The same goes for polarity, whose differences are not supported by the regression either.

On the socio-stylistic level, the phenomenon is only sensitive to the socio-cultural status of the speakers. As expected, the queista choices are significantly lower among speakers with a higher education, who are assumed to be more sensitive to the pressures of the prescriptive norm (.35). These are followed, in almost neutral figures, by the secondary education group $(.52)$ and, with far more favourable figures, by individuals with an elementary education (.64), who rank as the main promoters of these vernacular variants. In fact, $75 \%$ of the tokens in this group correspond to these variants, as opposed to only $25 \%$ that opt for prepositional forms.

The other extralinguistic predictors are discarded by the regression analysis. Neither gender nor age shows any explanatory force, but neither do the two factor groups that most interest in this study because of their potential link with contact: the speech community and the dominant language. If we start with the former, in Figure 1 we can see how the proportions of queismo obtained in each community (Alcalá, Madrid and Castellón) are very similar. Moreover, when the first two are grouped within a single dialectal block and compared with the speakers from Castellón, the regression analysis also rejects the null

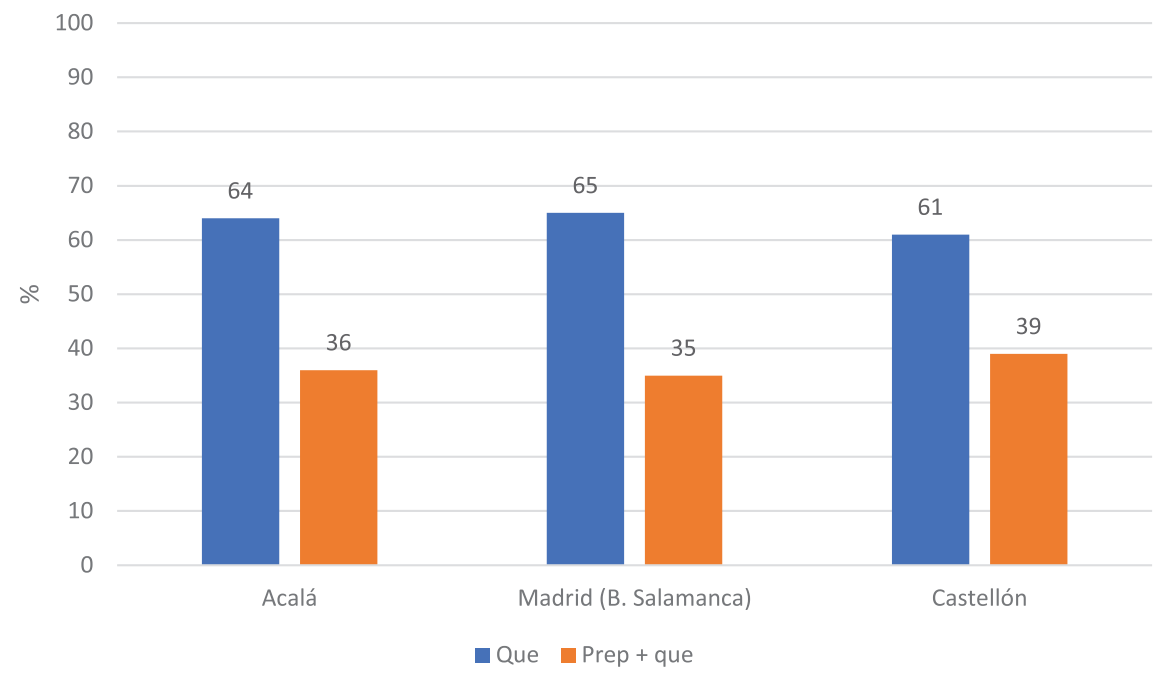

FIGURE 1 Distribution of the variants by speaking communities (\%) 
hypothesis (see Table 5). Consequently, no differences seem to be derived in relation to the environmental presence of Valencian-Catalan in the linguistic repertoire of the Castellón speech community. In fact, and contrary to what we would expect if this hypothesis were confirmed, the queismo variants in the region of Madrid (64\%) slightly exceed those of Castellón (61\%).

These results are strengthened by the figures for the dominant language. Indeed, in Table 5 it can be seen how the proportions of queísmo are strikingly similar between Spanish speakers (63\%) and Valencian speakers (62\%). And not only when we compare both groups in the whole sample, but also when the comparison is limited to the Castellón community. In the latter, the figures are again practically identical ( $6 \circ \%$ vs. $62 \%$, respectively).

Even so, we have previously stressed that differences in frequency can only give us a partial picture of the panorama that displays the variation, even when the proportions observed are similar. In practice, it could occur that, despite these similar general magnitudes, the variation patterns show deeper differences, either in the grammar or in the stylistic axis, if not in both. To test this possibility, in the following section we summarise the main results of a comparative analysis performed on the two ethnolinguistic groups considered: dominant Spanish speakers and dominant Valencian-catalan speakers. To do so, we carry out two independent regression analyses, one for each group, which take into account all the other linguistic and extralinguistic factors considered. The existence of significant differences between the results of these analyses would put us on the track of a different variable conditioning for each group, which would allow us to rescue the contact hypothesis. Otherwise, this hypothesis would lose strength, and would show that this conditioning does not differ in essence according to the speakers' main language.

\subsection{Spanish Speakers vs. Valencian Speakers}

The results of this comparative analysis are detailed in Table 6. The first four columns show the figures related to the group of the dominant Spanish speakers, while the other four offer the figures for the group of Valencian-Catalan speakers.

Of the two potential interpretations with which we closed the previous section, the data clearly endorse the second. With small differences in the details, the similarities between the two groups are obvious, both in terms of selected and unselected factor groups, and the direction of effect. As regards the former, the common favouring influence of relative clauses in the rates of queismo is again apparent, as well as the positive role of frequency, in such a way that the most recurring structures encourage prepositional elisions to a greater extent than those that appear less frequently. Likewise, at the sociolectal level, the 
TABLE 6 Comparative contribution of several linguistic and extralinguistic predictors to the selection of queísmo variants by dominant language



SPANISH SPEAKERS: $N=1278$; INTERCEPT: -0.039 ; LOG.LIKELIHOOD: -682,674; AIC: 1379,437; DXY: .70; INPUT: .63

VALENCIAN-CATALAN SPEAKERS: $N=558$; INTERCEPT: -0.056; LOG.LIKELIHOOD: -304,078; AIC: 620,308; DXY: .70; INPUT: .62

differences in educational status follow the same direction outlined above: the queista forms are favoured by individuals with a lower degree of education, followed by those with intermediate levels (secondary education). Conversely, the lowest rates of queismo appear among the speakers with a higher education. In 
the same way, the non-selected predictors (priming, polarity, gender, age) are also common to both groups.

However, the table shows an exception concerning the degree of adjacency between the governing element and the complementiser. We see how the difference between adjacent and non-adjacent contexts is neutralised among the dominant Valencian speakers, but not so among the Spanish speakers, in whom the same direction of effect highlighted in the previous section

TABLE 7 Comparative contribution of several linguistic and extralinguistic predictors to the selection of queísmo variants by dominant language (Castellón only)

\begin{tabular}{|c|c|c|c|c|c|c|c|c|}
\hline & \multicolumn{4}{|c|}{ SPANISH SPEAKERS } & \multicolumn{4}{|c|}{$\begin{array}{l}\text { VALENCIAN-CATALAN } \\
\text { SPEAKERS }\end{array}$} \\
\hline & $\mathbf{N}$ & $\%$ & $\Sigma$ & FW & $\mathbf{N}$ & $\%$ & $\Sigma$ & FW \\
\hline \multicolumn{9}{|l|}{ Type } \\
\hline Verbs & 104 & 39 & 262 & .37 & 78 & 37 & 213 & $\cdot 32$ \\
\hline Relative clasuses & 239 & 78 & 307 & 63 & 267 & 77 & 345 & .68 \\
\hline \multicolumn{9}{|l|}{ Priming } \\
\hline No & 216 & 56 & 383 & .38 & 257 & 64 & 404 & - \\
\hline Que & 94 & 67 & 141 & .54 & $5^{2}$ & $5^{1}$ & 101 & - \\
\hline Preposición & 33 & 73 & 45 & $.5^{8}$ & 36 & 68 & $5^{6}$ & - \\
\hline \multicolumn{9}{|l|}{ Polarity } \\
\hline Afirmative & 305 & 62 & 492 & - & 300 & 62 & 480 & - \\
\hline Negative & 38 & 49 & 77 & - & 45 & $5^{8}$ & 78 & - \\
\hline \multicolumn{9}{|l|}{ Adjacency } \\
\hline Adjacent & 301 & 59 & 507 & - & 313 & 62 & 507 & - \\
\hline No & 42 & 67 & 62 & - & 32 & 63 & 51 & - \\
\hline Frequency (continuous) & \multicolumn{4}{|c|}{+10.002} & \multicolumn{4}{|c|}{+10.001} \\
\hline \multicolumn{9}{|l|}{ Gender } \\
\hline Males & 128 & 63 & 201 & - & 117 & 60 & 194 & - \\
\hline Women & 215 & $5^{8}$ & 368 & - & 228 & 62 & 364 & - \\
\hline \multicolumn{9}{|l|}{ Level of education } \\
\hline Elementary & 106 & 77 & 138 & .67 & 125 & 75 & 167 & .63 \\
\hline Secondary & 142 & 61 & 231 & .46 & 142 & 60 & 235 & .45 \\
\hline Higher & 95 & 47 & 200 & $\cdot 36$ & 78 & $5^{\circ}$ & $15^{6}$ & .41 \\
\hline Age (continuous) & & & & - & & & & - \\
\hline
\end{tabular}

SPANISH SPEAKERS: $N=1278$; INTERCEPT: -0.002; LOG.LIKELIHOOD: -320,256; AIC:

620,769; DXY: .68; INPUT: .60

VALENCIAN-CATALAN SPEAKERS: $N=558$; INTERCEPT: -0.056; LOG.LIKELIHOOD: -304,078; AIC: 620,308; DXY: .70; INPUT: .62 
can be observed: adjacency somewhat disfavours queismo (.44), whereas the remaining contexts moderately favour it (.56) (for more details, see Section 6.1). Nonetheless, it could be that these differences were related to the size of the respective samples. In this respect, remember that the Valencian-speaking sample $\left(\mathrm{N}=55^{8}\right)$ represents a little less than half of the Spanish-speaking sample $(\mathrm{N}=1276)$, since it includes both the individuals from Castellón whose dominant language is Spanish, and all the informants from Madrid, who are all monolingual Spanish-speakers. Thus, and to avoid the bias that this sampling imbalance could entail, we run an additional analysis, this time taking into consideration only the data from the Castellón community. The results of this new comparative examination are shown in Table 7 , where the figures for the two samples are now far more balanced (Spanish speakers: $\mathrm{N}=569$; Valencian speakers: $\mathrm{N}=55^{8}$ ).

The results of this new analysis essentially confirm the results outlined so far. The favourable influence on queista variants, both among the dominant Spanish speakers and among the dominant Valencian speakers in Castellón, is led by the type of queísmo (relative clauses), the frequency of the constructions (the greater the recurrence, the higher the frequency of queismo) and the socio-cultural status (the greater the level, the lower the rates of the queista variant). Even in this case, the incidence of the adjacency is also neutralised for Spanish speakers, unlike what we observed in the general sample (Table 6).

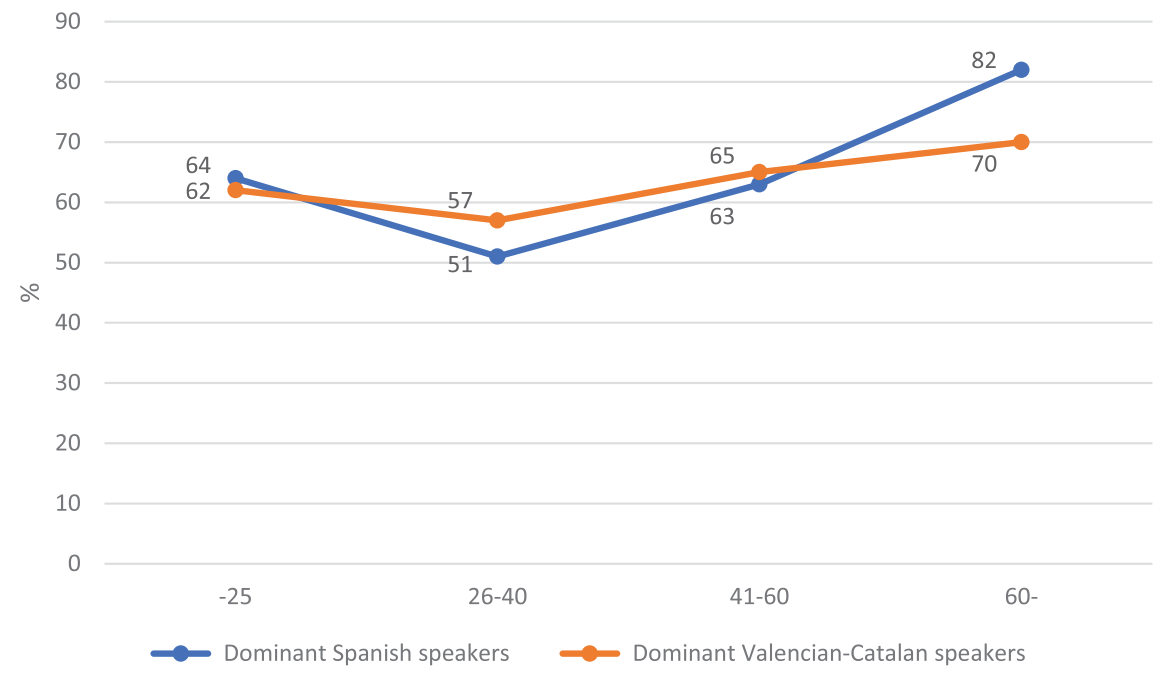

FIGURE 2 Cross tabulation between the dominant language and four age groups (Castellón only) 
Moreover, crossing with other predictors shows some additional examples of parallelism between the two groups. This is what occurs, for instance, when we analyse the speakers' age. Although this factor is not selected as a sufficiently robust predictor, the fact is that a comparison of the figures of the different age groups, such as that shown in Fig. 2, reveals some noteworthy similarities between Spanish speakers and Valencian speakers.

With some differences in the details, both ethnolinguistic groups coincide in the prevalence of queismo among the more advanced age groups, a distribution observed in other cases of vernacular variation, and which can been justified by the lower pressures of the standard among individuals who are generally more free from the constraints exerted by social and material progress (Labov, 2001; Chambers, 2009; Tagliamonte, 2012). This finding is in contrast to the representatives of early adulthood (26-40), in which these pressures act with more intensity and which in turn act as a brake hindering vernacular variants such as queísmo. It therefore seems revealing that among both Valencian speakers and Spanish speakers the lowest rates of queismo appear precisely in this age group. ${ }^{13}$

The only predictor with a significant difference between the two ethnolinguistic groups is now discursive priming. Although the tenor of the figures is identical in both (as expected, the presence of the preposition in the previous context seems to exert a common dissimilar effect, which favours elisions), the predictor is only selected among the dominant Spanish speakers, but not among the Valencian speakers.

\subsection{Variation within Conjunctive Queísmo}

We began this article by pointing out the existence of a greater structural conflict between Spanish and Catalan in the domain of verbal constructions than in that of relative clauses. While in the latter the speaker can alternate between prepositional and non-prepositional variants in both languages, constructions equivalent to Spanish conjunctive queísmo appear without a preposition in Catalan, at least in the standard variety (see Section 2). Hence, it could occur that the hitherto unnoticed differences emerge more clearly in this group of verbal constructions. If this is the case, the incidence of extralinguistic predictors such as the speech community or the dominant language of

13 Another possible interpretation of these generational differences would lead us to consider that the age of the speakers could reflect prior changes in the speech communities around this variation. However, the fact that the predictor has not been selected as sufficiently robust by the regression, and that the distributional pattern obtained is not exactly linear leads us to be cautious in this regard. 
TABLE 8 Contribution of various linguistic and extralinguistic predictors to the selection of queísmo variants in verbal constructions

\begin{tabular}{|c|c|c|c|c|}
\hline & $\mathbf{N}$ & $\%$ & $\Sigma$ & FW \\
\hline \multicolumn{5}{|l|}{ Type } \\
\hline Pronominal Verbs & 46 & 46 & 100 & - \\
\hline Non-Pronominal Verbs & 76 & 39 & 193 & - \\
\hline Verbal phrases & 170 & 40 & 427 & - \\
\hline \multicolumn{5}{|l|}{ Priming } \\
\hline No & 191 & 39 & 491 & - \\
\hline Que & 78 & 46 & 170 & - \\
\hline Preposition & 23 & 39 & 59 & - \\
\hline \multicolumn{5}{|l|}{ Polarity } \\
\hline Afirmative & 239 & 41 & $5^{82}$ & - \\
\hline Negative & 53 & 38 & 138 & - \\
\hline \multicolumn{5}{|l|}{ Persona } \\
\hline 1. ${ }^{\mathrm{a}}$ person & 137 & 47 & 294 & .55 \\
\hline Others & 155 & 36 & 426 & .45 \\
\hline \multicolumn{5}{|l|}{ Adjacency } \\
\hline Adjacent & 248 & 39 & 629 & - \\
\hline No & 44 & 48 & 91 & - \\
\hline Frequency (continuous) & 0.003 & & & +1 \\
\hline \multicolumn{5}{|l|}{ Gender } \\
\hline Males & 130 & 41 & 319 & - \\
\hline Women & 162 & 40 & 401 & - \\
\hline \multicolumn{5}{|l|}{ Level of education } \\
\hline Elementary & 87 & $5^{2}$ & 168 & .59 \\
\hline Secondary & 119 & 45 & 262 & .55 \\
\hline Higher & 86 & 30 & 290 & .35 \\
\hline \multicolumn{5}{|l|}{ Communities (grouped) } \\
\hline Castellón & 110 & 45 & 245 & .55 \\
\hline Madrid & 182 & 38 & 475 & .44 \\
\hline \multicolumn{5}{|l|}{ Dominant language } \\
\hline Spanish & 214 & 42 & 507 & - \\
\hline Valencian-Catalan & 78 & 37 & 213 & - \\
\hline Age (continuous) & 0.013 & & & +1 \\
\hline
\end{tabular}

$N=720 ;$ INTERCEPT: -0.732; LOG.LIKELIHOOD: -450,856; AIC: 915,87; DXY: .76; INPUT: .40 
the individuals would have to show greater differences than those observed so far; that is to say, conjuctive queismo should be favoured in the most autochthonous contexts, such as the Castellón speech community and, within this, among the dominant Valencian speakers.

In order to test these final hypotheses, we perform a new regression analysis, in which only the cases of conjunctive verbal queismo are taken into account. This analysis considers the predictors examined so far, in addition to the type of construction (pronominal verbs, non-pronominal verbs and verb phrases) and the person of the verb (1st, 2nd and 3rd), which we had reserved for the examination of this kind of structures (see Section 5). The results of this new analysis are shown in Table 8.

As can be seen, the patterns of variation of verbal queismo show certain points matching those observed earlier, but also a number of specificities that should be mentioned. Among the former, it is worth highlighting the favourable influence of frequency, such that the rates of elision are higher in the most frequent constructions in discourse. Conversely, our data do not support the hypothesis that queísmo is especially abundant in nominal colocations with supporting verbs (darse cuenta (de) que, no caber duda (de) que...), as has for some time been suggested (Fernández Ramírez, 1951: 129; Gómez Torrego, 1999: 2136). Table 8 shows that the differences among the verbal constructions are minor and in no case significant. As regards the sociolectal conditioning, it continues in the same direction of effect that was pointed out at all times: queismo follows a pyramidal structure by which the highest figures are found among the least educated speakers (.59), exactly the opposite to what occurs in individuals with a university education (.35), who are apparently more constrained by normative pressures.

One of the specificities is the incidence, which has not been considered until now, of the grammatical person. The data confirm the results obtained so far in relation to the general phenomenon of (de)queismo, according to which, the elision of the preposition is favoured in the cases of the 1st person (.55), a fact that has been related to the expression of evidentiality (Schwenter, 1999). Whatever the case, unlike the results of this author, in whose study this predictor occupies the most relevant position among those selected by the statistical analysis, in our study the relevance of the person is far more moderate, as can be seen from the factor weight values obtained. On the other hand, the expected scale, according to which the 2nd person would show significantly higher rates of elision than the 3 rd is not confirmed, and hence the two have been grouped for regression analysis purposes.

14 These results differ from those found by Gómez Molina and Gómez Devís (1995: 210 et seq.), who in the city of Valencia find more queísmo among young people. 
60

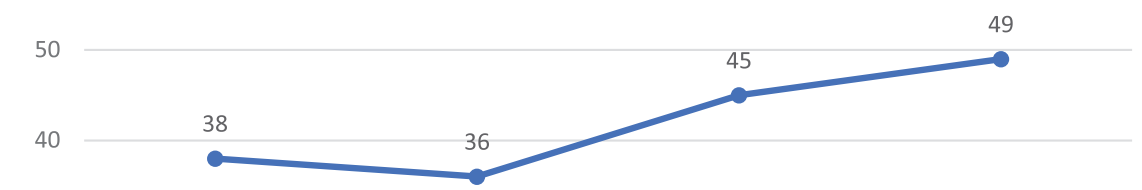

๙ீ 30

20

10

0 $-25$

$26-40$

$41-60$

$61-$

- Queísmo

FIGURE 3 Distribution of frequencies of queísmo in verbal constructions by age groups (\%)

On the social level, another difference with respect to what has been seen so far concerns age, selected this time as a significant predictor. On grouping the speakers in the four age brackets referred to above, conjunctive queismo shows a clear caesura between the youngest representatives of society (groups 1 and 2) and the rest, with the highest figures again among those over 6o years of age. This profile, in which different pressures of the standard are discerned again between the youngest - either because of their recent passage through the educational system (under 25 years old) or due to those inherent in entering the social and occupational world (from 25 to 40 years old) - and the older adults (groups 3 and, above all, 4 ), can be seen graphically in the Fig. $3 .{ }^{14}$

However, of more interest for the purposes of our study are the results associated with the two predictors especially linked to the potential influence of contact. In this sense, another salient finding is the null significance of the differences related to the individuals' dominant language. The same does not happen, however, with the community, which is now selected as an explanatory predictor, although in a direction contrary to the hypothetical influence of contact. Thus, far from Castellón being the community that is most favourable to the queista variants as the environmental presence of ValencianCatalan would suggest, in the study it appears to be the least prone to them (.44), in contrast to the Madrid communities, which moderately favour their appearance (.55). 


\section{Conclusions}

Within the framework of variationism, in this study we have tested the hypothesis concerning the potential influence of contact with Catalan on the variation experienced by queismo in some varieties of peninsular Spanish, which had been proposed previously in the literature. Through the analysis of three recently compiled oral corpora, two representative of central Spanish (Alcalá de Henares and Madrid (the Salamanca district)) and the other representing the Spanish in contact with the Valencian variety of Catalan (Castellón), in this work we have tested several linguistic and extralinguistic factors traditionally evaluated in the study of this syntactic variable, to which some others have been added in an attempt to determine this potential influence with more precision. Thus, in the linguistic plane, together with the incidence of previously analysed predictors (degree of adjacency, polarity, frequency, priming and person), we have also considered the hypothetical influence of the type of queísmo, which distinguishes between the conjunctive queísmo of verbal constructions and the pronominal one, which takes place within subordinate relative clauses. While in the latter, the structural coincidence between the two languages in contact is greater, in conjunctive queismo there are points of conflict between the two languages that, if the contact hypothesis is confirmed, would favour queista choices. On the other hand, the social axis is represented by the traditional predictors (sex, socio-cultural level and age), as well as the speech community and the dominant language of the speakers.

The results of this analysis refute, however, the influence of contact. Thus, we have confirmed that, both in queismo considered overall and in conjunctive queismo, in which the influence is sensed to be greater, none of the above mentioned factors function as expected. Neither the type of construction nor the community or the dominant language give rise to any differences that indicate the influence of contact with Catalan. Only in conjuctive queismo does the community show a small incidence, but this is contrary to expectations, and the highest rates are observed in the cities of Madrid -far from Catalan-speaking territories- and not in Castellón. At the same time, the comparative analysis of the two ethnolinguistic groups considered (Spanish dominant speakers and Valencian dominant speakers) shows a noticeable similar conditioning. With only a few minor exceptions, variation is affected by the same linguistic and extralinguistic constraints.

The profile revealed by this variation offers some similarities, but also some relevant differences with respect to another convergence phenomenon in which the influence of Catalan has traditionally been underlined, namely, the 
deontic uses of the periphrasis haber de + infinitive. From a historical point of view, elsewhere we have seen how, in the progressive loss of uses of this periphrasis in favour of tener que + infinitive between the nineteenth and twentieth centuries, the pattern of Catalan-speaking communities has differed to some extent from that found in other peninsular areas far removed from any contact (Blas Arroyo, 2015). On the one hand, the historical series shows that, in the passage from the nineteenth to the twentieth century, the abrupt decrease in the use of haber de is curbed in the Catalan speaking communities, where an homophone periphrasis -haver de- is the only one that express deontic modality in Catalan. However, these differences do not prevent the inner grammar of variation from being essentially similar to that offered by the other peninsular varieties. These differences in frequency in the use of the periphrasis which, nevertheless, follow a similar internal evolution (although at a slower pace in the case of Catalan) therefore present a different panorama to that observed in these pages in relation to queismo. In the latter, not only is the internal grammar or the sociolinguistic matrix of variation identical in the two dialectal areas and the two ethnolinguistic groups considered, but it is also identical in terms of frequency.

What could be the reasons that account for these differences between apparently similar phenomena? In order to answer this question, it is probably necessary to remember the nature of the phenomenon studied in these pages in Catalan. As the grammarians of this language recall, the dropping of the preposition in clauses introduced by que, despite the fact that the core word is generally constructed with one ("s'entesta en les seves pretensions", but "s'entesta que li donen un càrrec"), represents an "anomaly" that is often non observed in the spoken language. Hence, despite the dictates of tradition and the norm, in spoken Catalan (not so much in writing, although examples are also found) prepositional uses are commonplace. As noted by Badia (1994: 55), from whom we borrowed the previous examples, together with the canonical structure transcribed above, in oral Catalan "...en què li donen [un càrrec] can often be heard". And he concludes: "... in the most common speech the use of the preposition is constant, in contrast to the grammatical rule; the use of the preposition is justified by the analogy to cases in which its presence is correct [relative or interrogative què], and by that of the corresponding constructions in Spanish" (our italics). In short, analogy as a "corrector" of syntactic irregularities and the stimulus provided by parallel structures in Spanish represent a formidable obstacle hindering the triumph of the normative variants in Catalan.

As a line of future research, it would be interesting to compare the patterns of variation obtained in the present study with those observed in a Catalanspeaking corpus. This would allow us to accurately assess whether, in the 
Catalan linguistic communities, rather than the influence of this language on Spanish -far from being confirmed in this study-, we would not be actually witnessing the opposite direction of the contact, that is, the convergence of Catalan with the syntax of Spanish.

\section{Acknowledgement}

This study is part of the project "Structural, social and idiolectal dimensiones of linguistic change", funded by the Spanish Ministry of Economy and Competitiveness (Ref. F FI 2017-86194-P) and the University Jaume I (Ref. UJIB2017-01). I would like to thank two anonymous reviewers for their insightful and constructive comments. Any remaining errors are my sole responsibility.

\section{References}

Almeida, Manuel. 2009. (De)queísmo y variación sociolingüística en una comunidad urbana canaria. Revista de Filología 27: 9-30.

Arjona, Marina. 1978. Anomalías en el uso de la preposición de en el español de México. Anuario de Letras XVI: 67-90.

Badia, Antoni. M. 1994. Gramática Catalana. Madrid: Gredos.

Bentivoglio, Paola and Dexy Galué. 1998-1999. Ausencia y presencia de la preposición de ante cláusulas encabezadas por que en el español de Caracas: un análisis variacionista. Boletín de Filología de la Universidad de Chile XXXVII, Estudios en honor de Ambrosio Rabanales: 139-159.

Blas Arroyo, José Luis. 2004. El español actual en las comunidades del ámbito lingǘstico catalán. In Rafael Cano-Aguilar (coord.), Historia de la Lengua Española, 1065-1086. Barcelona: Ariel.

Blas Arroyo, José Luis. 2011. Spanish in Contact with Catalan. In Manuel Díaz-Campos (ed.), Handbook of Hispanic Sociolinguistics, 374-394. Oxford: Blackwell.

Blas Arroyo, José Luis. 2015. The scope of language contact as a constraint factor in language change: the periphrasis haber de + infinitive in a corpus of language immediacy in modern Spanish. International Journal of Bilingualism 19(5): 499-524. DOI: https://doi.org/10.1177/1367006914524644.

Blas Arroyo, José Luis. 2018. At the boundaries of linguistic convergence: variation in presentational haber / haver-hi. A sociolinguistic comparative analysis of Spanish and Catalan grammars. Languages in Contrast 18(2): 35-68. DOI: https://doi. org/10.1075/lic.oooo3.bla. 
Blas Arroyo, José Luis and Velando, Mónica. In preparation. El queísmo en la historia: variacióny cambio lingüístico en el régimen preposicional del español (siglos XVI-XXI).

Boretti de Macchia, Susana. 1989. (De)queísmo en el habla culta de Rosario. Anuario de Lingüística Hispánica 5: 27-48.

Bybee, Joan L. 2006. From usage to grammar: the mind's response to repetition. Language 82: 711-733.

Cano, Rafael. 1985. Sobre el régimen de las oraciones completivas en español clásico. In Julio Fernández-Sevilla (ed.), Philologica Hispaniensia in honorem M. Alvar, 81-93. Madrid: Gredos.

Carbonero, Pedro. 1992. Queísmo y dequeísmo en el habla culta de Sevilla: análisis contrastado con otras hablas peninsulares y americanas. In Elisabeth Luna Traill (ed.), Scripta philologica in honorem Juan M. Lope Blanch, II, 43-63. México: Universidad Nacional Autónoma de México.

Cestero, Ana María, Molina Martos, Isabel and Paredes, Florentino. 2012. La lengua hablada en Madrid: Corpus Preseea-Madrid distrito de Salamanca (CD-ROM). Alcalá de Henarés: Universidad de Alcalá.

Chambers Jack K. 2009. Sociolinguistic Theory: Linguistic Variation and Its Social Significance. Oxford: Wiley-Blackwell.

del Moral, Carlos G. 2004. Grammaticalization of Spanish 'de': reanalysis of (de) queísmo in Southern Cone dialects. Doctoral Thesis, University of Illinois at Urbana-Champaign.

Demello, George. 1995. El dequeísmo en el español hablado contemporáneo: ¿un caso de independencia semántica? Hispanic Linguistics 6/7: 117-152.

Fabra, Pompeu. 1956. Gramática catalana. Barcelona: Teide.

Fernández Ramírez, Salvador. 1951. Gramática española. Los sonidos. El nombre y el pronombre. Madrid: Manuales de la Revista de Occidente.

García, Erica. 1986. El fenómeno (de)queísmo desde una perspectiva dinámica del uso de la lengua. In José Moreno de Alba, (ed.), Actas del II Congreso Internacional sobre El español de América, 46-65. México: Universidad Nacional Autónoma de México.

García Yebra, Valentín. 199o. Claudicación en el uso de las preposiciones. Madrid: Gredos. Givón, Talmy. 1979. On understanding grammar. New York: Academic Press.

Gómez Devís, María B. 1996. El queísmo: causas explicativas y actitudes sociolingüísticas. In Antonio Briz, (ed.), Pragmática y gramática del español hablado, 311-316. Zaragoza: Pórtico.

Gómez Molina, José R. 2013. Las construcciones “de / Ø + que + verbo en forma personal”. In José R. Gómez Molina (ed.), El español de Valencia, 183-222. Bern: Peter Lang.

Gómez Molina, José R. and Gómez Devís, María B. 1995. Dequeísmo y queísmo en el español hablado de Valencia: factores lingüísticos y sociales. Anuario de Lingüística Hispánica XI: 193-220. 
Gómez Torrego, Leonardo. 1999. La variación en las subordinadas sustantivas: dequeísmo y queísmo. In Ignacio Bosque and Demonte Violeta (eds.), Gramática descriptiva de la lengua española 2. Las construcciones sintácticas fundamentales. Relaciones temporales, aspectuales y modales, 2105-2148. Madrid: Espasa.

Guirado, Krístel. 20og. (De)queísmo: uso deíctico y distribución social en el habla de Caracas. Caracas: Universidad Central de Venezuela.

Herrero Ruiz de Loizaga, Francisco J. 2005. Sintaxis histórica de la oración compuesta. Madrid: Gredos.

Johnson, Daniel Ezra. 20o9. Getting off the GoldVarb Standard: Introducing Rbrul for Mixed-Effects Variable Rule Analysis. Language and Linguistics Compass 3(1): 359-383.

Kany, Charles E. 1969. Sintaxis hispanoamericana. Madrid: Gredos.

Labov, William. 2001. Principles of linguistic change: social factors, vol. II. Oxford: Blackwell.

Lacreu, Josep. 200o. Manual d'ús de l'estàndard oral. València: Universitat de València. Lapesa, Rafael. 198o. Historia de la lengua Española. Madrid: Gredos.

Marvá, Jeroni. 1985. Curs superior de gramàtica catalana. Barcelona: Barcino.

Moreno Fernández, Francisco, Cestero Mancera, Ana María, Molina Martos, Isabel and Paredes, Florentino. 2002-2007. La lengua hablada en Alcalá de Henares. Corpus PRESEEA-ALCALÁ (edición en CD_ROM). Alcalá de Henarés: Universidad de Alcalá.

Ninyoles, Rafael. 200o. La societat valenciana: estructura social i institucional. Alzira: Bromera.

Pereira-Scherre, Maria M. and Naro, Anthony J. 1992. The serial effect on internal and external variables. Language Variation and Change 4(1): 1-13.

Pickering, Martin J. and Ferrerira, Victor S. 2008. Structural priming: A critical review. Psychological Bulletin 134(3): 427-459.

Poplack, Shana and Tagliamonte, Sali. 2001. African American English in the diaspora: Tense and aspect. Oxford: Blackwell.

Poplack, Shana. and Dion, Nathelie 2009. Prescription vs. praxis: the evolution of future temporal reference in French. Language 85(3): 557-587.

Poplack, Shana, Zentz, Lauren and Dion, Nathelie. 2012. Phrase-final preposition in Quebec French: An empirical study of contact, code-switching and resistance to convergence. Bilingualism: Language and Cognition 15(2): 203-225.

Rabanales, Ambrosio. 1974. Queísmo y dequeísmo en el español de Chile. In María Josefina Tejera (ed.), Estudios filológicos y lingüísticos. Homenaje a Ángel Rosenblat, 413-444. Caracas: Instituto Pedagógico.

RAE (Real Academia Espale) and ASAle (Asociación de Academias de la Lengua Española). 2005. Diccionario panhispánico de dudas https://www.rae.es/dpd/(last access 2-07-202O)). 
RAE (Real Academia Espale) and ASAle (Asociación de Academias de la Lengua Española). 2009. Nueva gramática de la lengua española. Madrid: Espasa.

Rosemeyer, Malte and Schwenter, Scott A. 2017. Entrenchment and persistence in language change: the Spanish past subjunctive. Corpus Linguistics and Linguistic Theory. DOI: https://doi.org/10.1515/cllt-2016-0047.

San Martín, Abelardo. 2016. Análisis sociolingüístico del queísmo en el español hablado en Santiago de Chile. Estudios Filológicos 58: 207-228.

Schwenter, Scott A. 1999. Evidentiality in Spanish morphosyntax: a reanalysis of (de) queísmo. In Serrano, María J. (ed.), Estudios de variación sintáctica, 65-87. Madrid: Iberoamericana; Frankfurt am Main: Vervuert.

Seco, Manuel. 1989. Diccionario de dudas y dificultades de la lengua española. Madrid: Espasa-Calpe.

Serradilla, Ana María. 1997. El régimen de los verbos de entendimiento y lengua en español medieval. Madrid: Universidad Autónoma de Madrid.

Silva-Corvalán, Carmen and Treffers-Daller, Jeanine (eds.). 2015. Language Dominance in Bilinguals: Issues of Measurement and Operationalization. Cambridge: Cambridge University Press.

Sinner, Carsten. 2004. El castellano de Cataluña. Tübingen: Max Niemeyer Verlag. Tagliamonte, Sali. 2012. Variationist sociolinguistics: change, observation, interpretation. Oxford: Wiley/Blackwell.

Torres Cacoullos, Rena. 2011. Variation and Grammaticalization. In Manuel Díaz Campos (ed.), Handbook of Hispanic Sociolinguistics, 148-167. Oxford: Blackwell.

Wheeler, Max W., Yates, Alan and Dols-Salas, Nicolau. 1999. Catalan. A Comprehensive Grammar. London, New York: Routledge. 